\title{
Multicultural Subjectivity and Cosmopolitan Identity: A Reading of Bharati Mukherjee's Jasmine
}

\author{
Altaf Ahmad Ganaie \\ Lecturer, \\ Department of English, \\ Govt. Degree College, Pampore
}

Human beings need a sense of identity and belonging. Individuals derive their sense of identity from their cultures and cultures are system of beliefs that determine how people live their lives. We also become who we are by developing a certain relationship to the past- not only our personal past, but also our family's and culture's past as well. So the Expatriate writers' narratives deal, mostly, with the internal strife in the context of cultural displacements. The immigrants away from the familiar ties oscillate between crisis and reconstruction. Idiosyncrasies and peculiarities offer a subtle and insightful commentary on their lives. The culture of the homeland etched in the minds of the displaced immigrants makes them outsiders in the new place of existence. Not able to or rather to say not willing to come out of that estranges them further. As a study in the construction of a subjectivity effect, Jasmine presents so interesting an example as to explain the desire to move beyond the embarrassment its critical reputation inspires. The heroine of the novel embodies a multicultural subjectivity. Jyoti - later called Jasmine, Jazzy, Jase, Jane, and then again Jase - tells her own story in a narrative sometimes reminiscent of her narratorial forbear Jane Eyre.

In Jasmine (1989), Mukherjee tries to unravel the complicated layers of cross-cultural reality through a series of adventures which the heroine undertakes during her odyssey from Punjab to California via Florida, New York and Iowa. Her struggle symbolizes the restless quest of a rootless person piqued by a depressing sense of isolation all around. The story opens with the village astrologer under his banyan tree foretelling jasmine's 'widowhood and exile'. It all turns out just as nastily as he says it will, but at the same time Jasmine is a survivor, a fighter and adapter. Her journey through life leads Jasmine through many transformations- Jyoti, Jasmine, Jase and Jane via divergent geographical locales like Punjab, Florida, New York, Iowa and finally California. At every step Jasmine revolts against her fate and the path drawn for her. The narrative shuttles between past and present, between India of the narrator's early life and America of her present one. The past is Jyoti's childhood in the small village of Hasnapur, Punjab, her marriage to Prakash Vijh and the consequences leading to her departure to America. Jasmine leaves for America on forged papers knowing not what future holds in store for her. But she is aware of the fate of her likes. She muses:

We are the outcastes and deportees, strange pilgrims visiting outlandish shrines, landing at the end of tarmacs, ferried in old army trucks where we are roughly handled and taken to ropedoff corners of waiting rooms where surly, barely wakened customs guards await their bribe.We are dressed in shreds of national costumes, out of season, the witted plumage of intercontinental vagabondage. We ask only one thing : to be allowed to land; to pass through; to continue (101). 
On first glance, Jyoti/Jasmine/Jase/Jane's names seem to map a progression of identities imposed upon her by men and by older, powerful women in the interest of keeping her fixed in place within the name giver's own sense of nationality. Indeed, the narrator comes close to acknowledging this, saying "I have had a husband for each of the women I have been. Prakash for Jasmine, Taylor for Jase, Bud for Jane"(175). The acquisition of each of her names occurs in the retrospective portions of the narrative, beginning with her childhood in India. Jyoti is her father's daughter, a Punjabi traditionalist whose early widowhood is supposed to mean the end of her own existence. She is named Jyoti, which means "Light", by her paternal grandmother, a fanatical adherent to the subordination of women. To accept her husband's renaming her Jasmine, however, she must adjust her relationship to Indian tradition, modernizing and globalizing her expectations to live up to his vision of Vijh and wife, that mythical corporation that was to take the couple out of India and into the western world. Even after her husband has died she refers to herself in terms of Vijh and wife, particularly during the period where she is learning to adjust to life in America while living with the Indian immigrants in New York. Once Taylor has renamed her "Jase", she begins to entertain the possibility of an American identity, which would seem to have solidified once she becomes settled, pregnant, Midwestern, plain Jane. Of course, there is nothing plain about her in the rural Iowa setting: Bud compares her looks to those of a maharani; Du's friends and Bud's neighbors are enchanted by the curries she cooks. "They get disappointed if there is not something Indian on the table" (7). Jane is certainly no longer simply Indian, but she is not not-Indian either: she is like the other women in her Iowa community and she is different. The specificity of her national difference does not matter to her Iowa neighbors. "To them....I'm a dark-haired girl in a naturally blond county. I have a 'darkish complexion' (in India, I'm 'whitish'), as though I might be Greek from one grandparent. I'm from a generic place, over there, which might be Ireland, France, or Italy. I'm not a Lutheran, which is not to say I might not be Presbyterian" (29). The neighbors acknowledge a difference, but they are not interested in what it might mean about who "Jane" is. Even Taylor's sophisticated friends in New York, who know enough to narrow their guesses at her nationality to Iranian, Pakistani, Afghan, or Punjabi, think she might be able to "help them with Sanskrit or Arabic, Devanagari or Gurumukhi script" (29). "I can read Urdu, not Arabic. I can't read Sanskrit", she tells the narrate (29), but these distinctions hardly matter once she has become "Jane".

Jasmine is very orderly, for what is being ordered is a new identity. The novel is inscribed in the old American pattern, the pattern of the frontier novel- the escape from the old identity, the old debts, the old wife to the new name, to the new life, and from the farm land of Punjab to the frontier of California. The reader is led from one consciousness to another as the illegal immigrant woman from the farm land of Punjab (India) blazes a trail of identities (JyotiJasmine-Jazzy-Jase-Jane) on her way to the frontier of California. It posits a norm of selfdevelopment. For an immigrant there are only two possibilities in Jasmine; either the Ghetto where ethnic identity is tightly secured by a minimal interaction with the outer alien worldan option that has its obvious short comings - or assimilation into the dominant white culture requiring nothing less than the radical rupture with the past. If expatriation is a great temptation and enemy of the "once third world" author, the preferred state of impatriation as it is described in Jasmine requires nothing less than the extinction of the once third world self.

Jasmine's transformation from Jyoti to Jane had its own scars and stresses. Jyoti, born in the small village of Hasnapur in the district of Punjab in India, marries a progressive young Indian man named Prakash Vijh who renames her as Jasmine. The cursed and hapless village girl in Jyoti becomes Jasmine, a city woman, wife of a modern man Prakash who wishes her "to call him by his first name" (77). This christening means much to her: 
He gave me a new name : Jasmine. He said: "You are small and sweet and heady, my Jasmine. You'll quicken the whole world with your perfume (77).

Being Indian, Jasmine had a very negative conception of the sexuality of American women and she worries when Prakash shows her a brochure of an American institute where he wants to pursue a course. She is conservative in her attitude though Prakash was helping in her transformation from Jyoti to Jasmine, she finds herself occupying both identities, shuttling between them and trying to understand the manner in which they both conflict and connect. This renaming can be viewed from the displacement point of view, for it brings to light the agency in Jasmine's formation of identity as well the conflict involved in the formation of that identity.

In unexpected circumstances Jasmine was widowed at a young age after the tragic death of her husband by a terrorist bomb in Jullundur. Heartbroken, after his death she decides to travel abroad to fulfill the dream of her slain husband. She thought it as a wifely duty to satisfy his lifetime desire thinking as "Prakash had taken Jyoti and created Jasmine, and Jasmine would complete the mission of Prakash"(97). When he was alive he was obsessed to leave India and settle down in USA. His aim in migrating was not just to satisfy his financial urge and make money, but he says, "When I go to work in another country, it will be because I want to be a part of it"(67).

Like her husband she wanted to be a part of it and she craves for love and belongingness in an alienated place, a craving, which could be traced all through the novel. The moment she lands, the challenges are flung at her one after the other. She had come to America without proper documents, and on the very first day of her arrival in the USA she was raped by the Captain of the 'The Gulf Shuttle' in which she had sailed from Europe to the coast of Florida. Finding herself without a place to stay Jasmine trusts him and accompanies to the motel, and he rape her thinking her to be not just an Indian but another Black. She avenged upon the Half-face, as she calls, because he had lost an ear, an eye, and a part of his cheek in the war, with a small knife. She turns violent not able to take the prejudiced notion against her and her identity. Jasmine then stabs Half-Face to death, "he stood and staggered, and with each stagger new spatter marks gushed against the walls, he tried to rise and couldn't. I pulled the bedspread off the bed and threw it over him and then began stabbing wildly through the cloth ..."(119).After the murder, Jasmine vows to start her life afresh, a life different from the past dependent and submissive one. The trauma of her rape results in the greatest change in her personality; the experience that breaks her down the most is also the greatest change in her individuality.

Jasmine doesn't want to give up because of the difficulties of adjustment; instead she wants to be a survivor to regenerate herself. But the process of adaptation was horrendous for her. She has come to realize that the notion of a singular identity in an alien place is a fallacy. After the migration, Jasmine, a small town girl, the socio-cultural values of the surroundings in which she was born and brought up was warped against her. Physically and culturally uprooted Jasmine, struggles single-handedly for her survival and self respect in an antagonistic world. She was straddling between two cultures and multiple identities, trying to establish her own identity. Stating the predicament of the immigrant in negotiating this dilemma Salman Rushdie observes: Human beings understand themselves and shape their futures by arguing and challenging and questioning and saying the un-sayable; not by bowing the knee, whether to gods or to men. 
Jasmine experienced violence right from her birth when her mother tried to kill her, and her future was predicted dark and dangerous when she hardly seven. She transcends personal tragedies, challenges the forces of death and destruction and ventures to seek personal identity in a bewildering and hostile world. Gradually she develops a sort of strategic adaptation of the new environment drawing strength from within herself and her surroundings. In that period of transition she says: "I keep my sandalwood Ganapati hidden in my purse, a god with an elephant trunk to uproot anything in my path" (20).

The character of Jasmine created by Mukherjee was capable of living in a world in which the individual exists not as a unified one but as many, bound by the circumstances, yet they strive relentlessly. Jasmine brought with her the new suit that Prakash got stitched for his visit to the states. She wanted to burn it in the school of Florida as a symbolic gesture of wifely duty so that her husband's soul could rest in peace. But before she could accomplish her task she had to encounter the dark, ugly face of American life.

Cultural change and the alienation from motherland complicate her identity crisis. Though selfconscious she was torn between the past and the present. In those circumstances she met with Lilian Gordon, who provides her with a temporary home and taught her how to become American and begin the process of assimilation. "I checked myself in the mirror, shocked at the transformation. Jazzy in a T-shirt, tight cords and running shoes. I couldn't tell if with the Hasnapuri modesty"(133). Gordon gave her the westernized nickname 'Jazzy', symbolic of her entry into the host culture. She gave her valuable insight to face life in the new world. Jasmine learns the American way of life and wants to blend herself with them. Gordon helps Jasmine by teaching the process of absorption and her daughter Kate gave her one of her most memorable experiences. Jasmine fondled her unusual pet, which made her feel reborn in America as at Indian villages girls do not hold large reptiles on their laps. She wanted to alter the tradition and begin afresh her life at twenty-two, this is symbolic of her transformation as a brave women.

Jasmine, determined as she was, not only works on assimilating her-self but also tries it with others too. She has been able to change Bud, Du and Darrel with regard to Indian food. She proudly tells, "They get disappointed if there's not something Indian on the table", and boasts: "I took gobi aloo to the Lutherian Relief Fund craft fair last week" (146). At the same time she is practical enough to understand that the influence is just temporary. She was sensible in her perception of the fact that Bud was never curious to know about India and her genuine foreignness frightens him. She with pragmatic approach into her new life after displacement has acquired wisdom, which was quite agonizing to her. As Jasmine's self-perception changes, she momentarily tries to be Jazzy, believing that Jasmine was a self of the past, but she soon learns that the past is one that never truly disappears. Though Gordon asserted "Let the past make you wary, by all means, but do not let it deform you", in reality it will not work out. In America, nothing lasts... It was the hardest lesson of all for the immigrants to learn. "We arrive so eager to learn, to adjust, to participate, only to find the monuments are plastic, agreements are annulled. Nothing is forever, nothing is so terrible or so wonderful, that it won't disintegrate" (159).

Jasmine then moves to an Indian family in Hushing, New York. There she felt as if it was the continuation of her earlier teenage days and thinks as it was as though she had never left India. But as Jasmine builds her life in America, she longs to forget her past and believes that it will make her static in a fast moving new world. "I could not admit that I had accustomed myself to American clothes ... to them I was a widow who should show a proper modesty of appearance 
and attitude"(181) .She wanted to break off from her past that was suffocating, the life of a widow at a quite young age.

When Jasmine went to live with the professor she wasn't able to adjust after getting used to staying with the American Lilian Gordon, though the family of professor ji was kind to her. That was ironical for her to think of the fact how she has changed. This has become something difficult to cope up with the duality of existence. She felt in that apartment of artificially maintained Indianness, she wanted to distance herself from everything Indian, everything Jyoti-like. Though Jasmine got herself a respectable identity in New York as Jase, 'care-giver' in a family for a while she was satisfied with her identity, but when her husband's killer, Sukkhi, came across her, she left New York and moved to Iowa. To wipe out her previous identities, Bud Rippleman, farmer turned banker gave her the name jane. Eventually she finds it hard to solve this perplexing problem of multi-identity. The ideals of freedom and individuality identified with America appear farce and ridiculous to her. In spite of all these grievances Jasmine was wise enough to make use of her immigrant experiences. She admits the fact that she will remain grateful to, Lillian Gordon, Taylor, Wylie Hayes, Du and all other with whom she has come in contact. Professor ji and his family who were very considerate towards her enlightened her with the sorry state of affairs prevalent there for aliens. She says, "they had taught me a great deal about surviving as an Indian in New York. If I had been a different person with a different set of experiences ... then Professor Ji's lessons would be life affirming, invaluable, inexpressibly touching" (209).

Jasmine was in a depressed state, as mentioned above with a different set of experiences, unable to understand her position as a culturally uprooted, re-rooted person. What is constant for her, she wasn't having a constant name, a very basic identity common to all. She comments on her predicament: "Jyoti of Hasnapur was not Jasmine, Duff's day mummy and Taylor and Wylie's au-pair in Manhattan; that Jasmine isn't this Jane Ripple Meyer and which of us is the undetected murderer of a half-faced monster, which of us has held a dying husband, which of us was raped in boats and cars and motel rooms?"(127).

One may ponder at the plight of poor Jasmine, what did she achieve at the end? Was the things aspired by her so difficult to attain? All this remains unanswered. Then was it her fault, can't be true, because the poor helpless woman was in search of belonging, and love in the new place. She was already physically and linguistically displaced from her native land, but the circumstances made her emotionally displaced. After marriage given a new name she was quite, after her arrival into an American family to earn a livelihood working again given a new name and when she went to Iowa once again a new name. Is the worth of a human being equal to some product, whoever uses brands it a pet name or with a patent right changes the label? Since her birth, when she was named Jyoti by her grandmother everyone played with her emotions, her identity as an individual. Once she was culturally uprooted she was in a dilemma how to compensate both the cultures, past culture and the host culture. But one thing should be recorded, culture cannot be a past thing, it will always remain in an individual's subconscious. That's where lies the heart of the problem, when one cannot get rid of the past history, how he can accommodate the host culture. With silken bond memories the immigrant is tied to his homeland, tender compassions and above all a sense of belonging is there in him towards his native land, when compared to present hostile host culture where experiences are traumatic. Jasmine after her arrival in Iowa unintentionally became a spoilsport in the life of Bud. His wife Karin labels her as a tornado causing destruction wherever it passes by. Jasmine tries to contemplate what she actually is. "I can honestly say all I wanted was to serve, be allowed to join, but I have created confusion and destruction wherever I go. As Karin says, I am 
a tornado. I hit the trailer parks first, the prefabs, the weakest links. How many more shapes are in me how many more selves, how many more husbands?" (215)

The protagonist in the end decides to leave Bud, who was the father of her unborn child. She has decided that adventure, risk, and transformation have become a part of her life, and have become inevitable for her. While moving away from there she is optimistic and says, "Watch me reposition the stars." (226). The theme of Jasmine is an Indian immigrant's encounter with the New World and her gradual transformation as she strives to imbibe the new culture of existence. The novel also orchestrates a quest for identity: how a woman, rather an immigrant comes to term with her own self. As Sumita Roy points out in an article, Jasmine's search for self-recognition takes her in social and spiritual directions. . .till she arrives at a time when she can view the future greedy with wants and reckless from hope. Jasmine and the minor yet important character $\mathrm{Du}$, symbolize the new life form emerging from the east-west encounter. Contentment not yet reached, in such beings, results in violence, turmoil, and agony at all levels-personal, social and international, almost all are the resultants of cultural uprooting and re-rooting. Jasmine possesses an evolving identity that is unpredictable and filled with possibilities changing with her every new environment. The frequent use of alienation as a centering focus is due to the fact that it is common to all humans. Alienation is a feeling of not belonging. This feeling can be physical, mental, religious, spiritual, psychological, political, social, or economic and often it tends to be a combination of more than one of these types.

Thus Mukherjee's novel Jasmine a masterpiece represents the trials for assimilation and resultant cross-cultural ambiguity. So is the experience of Jasmine in America and the culturally displaced figure of Mukherjee, endless sea of voyages whose non-existence ends promise opportunities but rarely deliver, it is a life of uncertainty and has a broken image. After displacement caught between two worlds, the immigrant negotiates a new space with the amalgamation of both the cultures. She tries to accommodate her home culture by pushing farther, the boundaries of the host culture. The novelist has carved a niche for herself among the best writers of expatriation, as the aforesaid words aptly suggest.

\section{Works Cited}

Dimri, Jaiwanti. "From Marriage to Murder: A Comparative Study of Bharati Mukherjee's Wife and Jasmine”. American Literature Today. Ed. Suman Bala.New Delhi: Prestige Books, 1994, p. 173. Print.

Kumar, Nagendra. The Fiction of Bharati Mukherjee: A Cultural Perspective. New Delhi: Atlantic Publishers, 2013. Print.

Mandal, Somdatta. Bharati Mukherjee: Critical Perspectives. New Delhi: Pencraft Books, 2010. Print.

Mukherjee, Bharati. Jasmine. New York: Grove Weidenfeld, 1989. Print.

Nelson, Emmanuel S. Bharat Mukherjee: Critical Perspectives.New York: Garland Publishing, 1993. Print.

Roy, Sumita. “Jasmine: Exile as Spiritual Quest,” Indian Women Novelists.Ed. R.K. Dhawan. New Delhi: Random House, 2005. Print.

Tandon, Sushma. Bharati Mukherjee’s Fiction: A Perspective. New Delhi: Sarup \& Sons, 2013. Print. 